\title{
Indispensable Successful
} Implementation Features for ELearning in the Egyptian Higher Education

\author{
Dr. Tamer Sameer AbdEl-Badea
} Lecturer in Instructional Technology Faculty of Specific Education Tanta University- Egypt 



\title{
Indispensable Successful Implementation Features for E-Learning in the Egyptian Higher Education Dr. Tamer Sameer AbdEl-Badea (*)
}

\begin{abstract}
E-leaning has become every day and commonplace in higher education across the world. In some institutions, opportunities and finances of technology have yet to be fully utilised. To better enable the initial exploitation of e-learning, this paper describes the development of a theoretical construct, based on original research, describing the characteristics associated with the successful deployment of technology evidenced in Egyptian higher education supported by the concepts of a technology acceptance model. The theoretical construct is designed to both, reflect the research findings and, support developments in e-learning. indispensable success features based around the quadrant of curriculum, tutors, learners and technology. Findings illustrate the importance of curriculum content specifications (theoretical, practical); tutors' features (attitude towards e-learning, proficiency of the technology, and support); Learners' features (computer competency, English language proficiency, and learning style); and Technological feature (usability, affordances and infrastructure) for successful e-learning implementation.
\end{abstract}

It is concluded that by systematically considering these features the implementation of e-learning and blended learning can be more effective and efficient.

Keywords: e-learning, indispensable success features, Egyptian higher education, e-learning in higher education.

* Lecturer in Instructional Technology- Faculty of Specific Education- Tanta University- Egypt 
أصبح التعلم الاككترونى العامل المشترك اليومى فى التعليم العالى فى كافة أنحاء العالم. ففى بعض المؤسسات التربوية, الفرص والتمويل للتكنولوجيا مازالت تحت التكوين

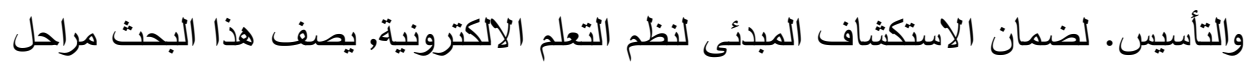
تطوير بناء نظرى مبنى على بحث فعلى يصف الصفات المرتبطة بالتوظيف الناجح

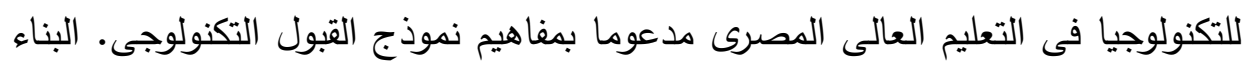

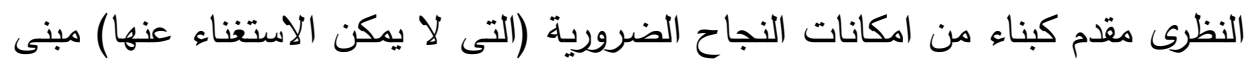

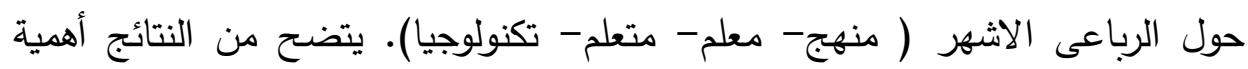
طبيعة محتوى المنهج ( نظرى - عملى)؛ خصائص المعلمين (الاتجاه نحو التعلم الإلكترونى- التمكن التكنولوجى - الدعم)؛ خصائص المتعلمين (الكفاءة الكمبيوتريةكفاءة اللغة الإنجليزية- أسلوب التعلم)؛ و التكنولوجيا ( سهولة الاستخدام- الامكانات والبنية التحتية) لضمان التطوير الناجح لبرنامج التعلم الالكترونى. الكلمات المفتاحية: التعلم الالكترونى- خصائص النجاح التى لا يمكن الاستغناء عنها - التعلم الالكترونى فى التعليم العالى. 


\section{Introduction}

According to UNESCO education report (2003), higher education in Egypt has been, like many Arab countries, suffering a stressful enrolment rate. In addition to, the threats of (COVID 19) spread among learners which created a strong bond between technology usage and educational systems around the globe. evidences of higher education sector's sufferings in 2020, appeared in learning institutes' closure around the world for 79 instruction days on average, ranging from 53 days in high-income countries to 115 days in lower-middle-income countries. Governments faced numerous challenges as they transitioned to distance learning, such as limited institutional capacity to support teachers, poor access for vulnerable populations, and lack of coherent policies and funds to support remote learning. (UNESCO, UNICEF, the World Bank and OECD, 2021).

The Egyptian higher education sector is not far from these challenges in addition to other cultural challenges of the aspiration to expand their ability to absorb the maximum learners' enrolment rate, Egyptian educational institution lacks the needed resources to do so, especially the financial ones. Being in a difficult demanding situation, among many expectations of providing a high quality lifelong education, it has become crystal clear that Egyptian higher education institutions lack the ability of fulfilling Egyptians' demands.

the review of UNESCO 2023 GEM Report on technology and education describes: "Technology appears in six out of the ten targets in the fourth Sustainable Development goal on education. These references recognize that technology affects education through five distinct channels, as input, means of delivery, skill, tool for planning, and providing a social and cultural context." (UNESCO. 2021). Such stress has been an outcome of two major features working together: government promises of expanding higher education usage of modern technologies in education; and young people's desire to obtain a better work opportunity mainly through a higher education.

Consequently, in order for the Egyptian higher education to support their educational systems, radical changes, plans, and 
visions, were strongly embraced by Arab countries, namely elearning. Yet, a vision that is hindered by many obstacles that makes the adoption and integration of modern educational technologies such as e-learning in the current educational systems almost impossible. Thus, the low usage level and the low quality of existing e-learning systems in Egyptian higher education are clear and logical compared to what is expected and required.

Research questions:

1. What are the Indispensable Successful Implementation Features for E-Learning in the Egyptian Higher Education?

2. What is the effectiveness of using e-learning on learners' achievement level in the "printing \& binding" course?

Research aims:

1. Generate a group of Indispensable Successful Implementation Features for E-Learning in the Egyptian Higher Education.

2. Create an e-learning course for the "printing \& binding" curriculum.

3. Indicate whether this e-learning approach is effective on learners' achievement levels or not.

Significance of the Research:

The purpose of this research is to: examine the effectiveness of e-learning; and present Indispensable Features to Successful Implementation for E-Learning in the Egyptian Higher Education. Therefore, this research gains its importance from:

1. The unique structure to examine the effectiveness of e-learning for the Egyptian higher education;

2. Establishing a group of Indispensable Successful Implementation Features for E-Learning in the Egyptian Higher Education. 
Context of the research:

According to Leggett \& Persichitte (1998), integrating technology into education is hindered by five categories of barriers i.e., (TEARS): "T" time (to plan, collaborate with peers, prepare lessons \& materials, explore, practice, evaluate, develop, maintain and expand skills); "E" expertise (technology training must be: available, hands-on, systematic, on-going); "A" access (must have uninterrupted, on- demand-inside \& outside classroom); "R" resources (to purchase, maintain, upgrade technology, training, support); "S" support (administrative \& technical). Added to that, modern technology integration into teaching and learning should be supported by, among other features, good teaching and self-efficacy (Antonacci 2002). Additionally, Nesterchuk, Grishin, and Chepurnaya (2020) identified the main barriers to the development and promotion of digitalization of the Russian educational environment (which could be argued that it is significantly equivalent to the Egyptian circumstances) as: Insufficient level of qualifications of teachers to work online as a format of new communication: lack or low level of educational services offered, distance interactive learning products; lack of an individual language for distance learning, a low level of knowledge of a foreign language by teachers of general education and higher institutions ‘Technical equipment: lack of technical equipment for some trainers and trainees.

Concerning challenges, the Egyptian learning environment is not any better if not even worse. Challenges as identified by many studies include: the severe shortage in number of teachers; poorly paid and trained low status teachers; over-population; large classes; and a centralised, test-driven memorisation oriented curriculum comprising boring irrelevant material (NCERD, 2001; Warschauer, 2003). Yet, Egyptian learner's anticipations are widening regarding new e-learning oriented courses especially after the (COVID 19) pandemic. For Egypt, among other developing countries, academics' relation to utilisation of technology is another barrier. In other words, faculty members, lecturers, and instructors have insufficient perquisite skills to utilise technology in teaching. This barrier grows harder as they are highly expected, by administrators and students, to incorporate technology into teaching and 
administration. In fact, this is an indispensable issue in higher education.

Concerning e-learning integration, the existing body of research highlights more challenges facing developing countries. For instance, in Iranian society, Yaghoubi et al. (2008: p. 90), identified a number of indispensable problems facing the shift from traditional education into a modern one: misunderstanding of students' educational needs at different educational stages; lack of real comprehension concerning the process of learning; defective implementation of computer hardware and software; weak IT education; lack of real strategic higher education planning; poor budget and poor equipment; complicated influential political, social and economic situations; and, above all, a severe shortage of digital literacy among tutors and learners.

These features, among many others, formed the starting point for considering the issues arising in the context of this research in Egypt.

The present research examines the Egyptian higher education indispensable success features from learners' view point, and identifies the relevant success features embedded in the Egyptian higher education learning environment and identifies the missing ones.

As stated by Beckstrom et al (2004), e-learning is not embraced as an official teaching and learning method by the Egyptian higher education. Even worse, the Supreme Council of Governmental Universities does not accredit any e-learning supported or delivered educational programmes. Yet, in Egypt, this official higher education rejection of e-learning as a learning supporting delivery method despite the haphazard utilisation of elearning systems in a wide range after the (COVID 19) pandemic reflects only one side of the dark picture.

To fully understand the e-learning implementation situation in the Egyptian higher education, its developmental history in the higher education learning sector has to be traced closely. As early as the beginning of 1994, the Egyptian learning environment witnessed some notable shifts marked by the Ministry of Education establishment of "Technology Development Centre" (TDC) which, 
by 1999, has already expanded to include more than 600 full-time working members (Warschauer, 2003).

The awareness of the importance of technology integration into the educational environment was accompanied by the gradually growth of Internet users in the Egyptian society. According to the Ministry of Information and Communications Indicators Bulletin (2020), Egyptian ADSL subscriptions number have arisen from 6.88 million in 2019, to 7.99 million subscribers in the second quarter of 2020. Thus, the growing number of Internet users in Egypt indicated that Egypt will, hopefully, have the ability to adopt e-learning in education as a delivery method, and also indicated that Egyptian education has the capacity to effectively engage with the e-learning once it has decided to be an official method to deliver Egyptian higher education curriculum.

Based on these promising potentials, the Ministry of Communications and Information Technology (2010) proposed the Egyptian Education Initiative (EEI) higher education track plan that was implemented across 17 public universities complementing the efforts of the Ministry of Higher Education to accomplish the following objectives: to increase access to technology; to qualify university staff, and administrators to use Information Technology efficiently; to promote e-learning as a basic component in the higher educational process to overcome the challenges related to large numbers, diversity and special needs; to integrate and activate the ICT aspect of the reform of faculties of education. These objectives were added to already existing objectives: providing quality and equality education for all, preparing young people to the global market, and developing competitive skills geared towards exporting services. In his research, Abdel-Wahab (2008) stated, "In order to provide the growing population of Egypt with quality, accessible, and abundant educational opportunities, both the government and the private sector are eager to develop alternative programmes and delivery methods." (p. 157). He then cites an e-learning implementation example that was initiated in 2005 to encourage and enhance e-learning utilization in teaching and learning, and other academic quests through a variety of academic and scholarly activities. 
despite, the Egyptian higher education appears to meet key pre-conditions for e-learning in terms of: technological capacity and digital skills ؛ Over $90 \%$ of students have access to the internet, Widespread computer and internet use, including with a strong focus on internet use for education purposes, suggest that students' digital skills are generally well-developed. Finally, higher education teachers appear to be largely well-prepared, as most have access to digital devices and computers and three quarters of teachers already use the internet for their work. The work on the ground shows that affordable access to rapid internet remains an issue, most students accessing the internet through mobile devices not through a common workspace, students' technological capacities and digital skills reflect important divides along gender, socioeconomic background, and location. (Ali, 2018; Al-araibi, bin Mahrin, Yusoff, \& Chuprat, 2019; Niehues-Jeuffroy \& Rusnak ,2020;)

It is undeniable that, In Egypt, e-learning is still crawling. Thus, educational organisations, government conferences, and educators are calling for more systematic research to develop an elearning theory and practices that best suits the Egyptian circumstances. Yet, in Egypt, the under-utilised new technologies problem continues despite the remarkable advances at the hardware and software levels. Thus, it is inevitable to fully absorb the conditions under which the educational institutions and their learners will embrace new technologies. In fact, it is a high-priority research issue. Consequently, an accelerating movement toward theorising the adoption of new technologies appeared. As a result, theoretical and empirical support has been particularly given to the Technology Acceptance Model (TAM) among other models (Davis, 1989).

Three widely used models include the Technology Acceptance Model (TAM), the Theory of Reasoned Action (TRA), and the extension of TRA into a Theory of Planned Behaviour (TPB) (Pedersen, 2003). The TAM presented by Davis (cited by van Akkeren and Cavaye, 1999) suggests that when a user is presented with a new technology, a number of factors influence their decision regarding how and when they will use it. This includes its perceived usefulness and its perceived ease of use. However, the TAM doesn't consider other factors that could be affecting new technology 
acceptance, such as: economic factors, outside influences from suppliers, customers and competitors (van Akkeren and Cavaye, 1999). The Technology Acceptance Model is shown in Figure 1.

\section{Figure 1: Technology Acceptance Model}

The core of the TAM model states that two basic beliefs determine an individual's behavioural intention to use a system:

1. Perceived usefulness, defined as the extent to which a person believes that using this new technology will enhance his/her job performance and will increase their opportunities to find better jobs;

2. Perceived ease of use, defined as the extent to which a

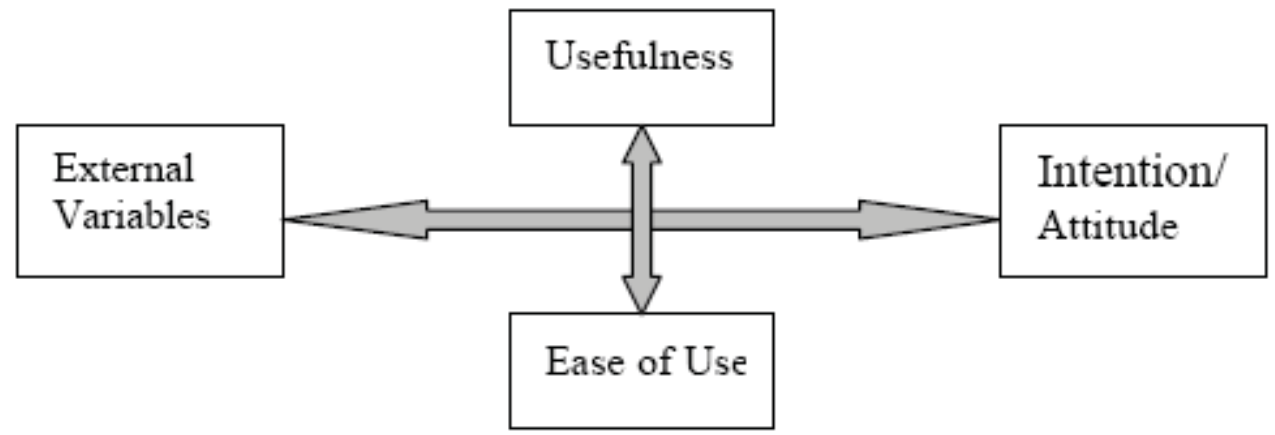

person believes that using the system will be free of effort (Davis, 1989: p. 320).

It is debatable that the effects of external variables such as: system characteristics, development process or training on "intention to use" are influenced by perceived usefulness and perceived ease of use. Teachers and learner's attitudes towards technology use are possible indispensable success features. The abilities to do computing using your own knowledge, skills and motivations could be called "computer self-efficacy", and it could be argued that a higher level of computer self-efficacy increases the use of e-learning. According to $\mathrm{Wu}$ (2010) and Lee (2010), perceived enjoyment, among many others, are exemplar features that indirectly affect the use of e-learning systems.

\section{Methodology:}

The present research used a wide context, multi-variant casestudy methodology (Yin, 2003: p. xi). The participants are students 
of first year-instructional technology department, Tanta University, Egypt). Data collection methods included a questionnaire ( $\mathrm{Q} N=65)$, focus group (FG N=3) (Bloor et al., 2001: p. 19); (Cohen et al., 2007: p. 228), and in-depth semi-structured interviews ( $\mathrm{I} \mathrm{N}=3$ ). Data collection methods were used to identify the learners' views regarding e-learning. Existing literature and related studies formed the basis for making decisions about e-learning structure and the methods of investigation. In addition to expert evaluation of the questionnaires translation from English into Arabic and table were designed by Arabic-speaking e-learning experts. Moreover, there was similar scrutiny of the translation of Arabic responses before the open and thematic coding analysis process conducted in English.

The participants were given the opportunity to construct their learning groups based on social preferences and circumstance giving them, in the spirit of e-learning, the freedom to learn how, when, and where they like. The open coding analysis process identified broad themes and then patterns including "The specifications of the course" and "Tutors' features". Next, the more detailed process of classification identified nodes, sub-nodes, tree nodes and utilised a data analysis program to identify the emerging themes. All these procedures followed the principles of grounded methods in the qualitative research (Corbin, 1998; Glaser, 1967).

In the present research, the following abbreviations are used: -FG - instead of -Focus Group- followed by the number of the group e.g. FG1, FG2, etc..., then the number given to each learner instead of his/her name (as a pseudonym). - Q - instead of Questionnaire - followed by the number of the respondent. - I instead of - Interview- followed by the number of the interviewee e.g. I1, I2, etc...

\section{Case Study Identification:}

The Dictionary of Sociology states, "Case Study; The detailed examination of a single example of a class of phenomena, a case study cannot provide reliable information about the broader class, but it may be useful in the preliminary stages of an investigation since it provides hypotheses, which may be tested systematically with a larger number of cases" (Abercrombie, 1984: p. 34). 
The previous definition of case study caused some quantitative researchers to argue that, if a case study is used to generate, but not to investigate the hypotheses, then it should be used as a stage in the research rather than the whole approach.

Qualitative researchers argue that rather than using large samples followed by examining a limited number of variables, the case study method involves an in-depth examination of a single instance or event. Researchers may gain an in-depth understanding of why an event happened as it did, and what it might be important to look at more extensively in future research.

Stake (1995: p. xi) identifies Case Study as, "The study of the particularity and complexity of a single case, coming to understand its activity within important circumstances." While, Gillham (2004: p. 1) defines it as "an approach that tries to represent a case through the investigating of an individual or a group such as a family, class, or an office".

Jaques (1994: pp. 75-114) lays out an interesting outline for describing what a case study should be and do:

1. Written summaries or syntheses of real-life cases based upon data and research;

2. Require you to isolate and think through the key issues involved against both theory and the larger comparative environment;

3. Identify appropriate strategies for the resolution of the 'case';

4. Weigh the pros and cons of the remedial options/strategies; and

5. Recommend and present a rationale for the best resolution.

From these definitions case study could be considered as: case (the single example), and study (the in-depth analysis). Thus, it means "a research conducted to examine in-depth a specific element." 


\section{Why Case Study?}

Literature reviews gave powerful points to guide researchers to use the case study approach in educational research.

Yin (2003: p. xi) stated that "case study is appropriate when investigators either desire or are forced by circumstances to: (a) define research topics broadly and not narrowly; (b) cover contextual or complex multivariate conditions and not just isolated variables; and (c) rely on multiple and not singular sources of evidence."

In order to investigate the pros and cons of e-learning systems and to define Challenges and opportunities of e-learning systems for the Egyptian higher education, this investigation covered multivariate study and used multiple methods to collect the data, which could indicate the opportunities for successful e-learning implementation in the Egyptian higher education sector.

The case study offers a revenue to investigate complex social events consisting of multiple variables of potential importance in understanding the phenomenon. In order to achieve this, case study allow researchers to use various data collection tools, it even allows them to use a variety of methods underneath the umbrella of a case study approach.

This methodology is the best way to determine the indispensable features that determine successful e-learning implementation.

Yin (2003: p. 4) stated "The case study method is the method of choice when the phenomenon under study is not readily distinguishable from its context".

This research is trying to study the effects of implementing an e-learning system in the Egyptian higher education context and broadly focuses on studying every element involved in the process of implementation and covers the complex multivariate conditions of the whole process relying on multiple data collection tools which shape the sources of evidence this research needs.

"An example of the complex interactions between the phenomenon and its context is the implementation of personal 
computers in schools (Yin, 2003: p. 4)". Which is similar to what this research is doing by studying the implementation of an elearning system in the Egyptian higher education context, trying to study all the indispensable features that determine successful implementation of e-learning.

Stake (1995) distinguished three types of case study which are defined by Helen Simons as:

1. Intrinsic: where the case is studied for intrinsic interest in the case itself;

2. Instrumental: where a case is chosen to explore an issue or research question determined on some other grounds, that is, the case is chosen to gain insight or understanding into something else;

3. Collective: where several cases are studied to form a collective understanding of the issue or question (Simons, 2009).

This research belongs to the instrumental case study type because it explores the case of the Egyptian higher education's usage of e-learning to gain visions and a better understanding of the indispensable features that determine successful implementation of e-learning. 
Table 1 Chronology of the data collection

\begin{tabular}{|c|c|c|c|}
\hline Method & What Happened & Where & When \\
\hline Pre-test & $\begin{array}{l}\text { An achievement test } \\
\text { know the prelimin } \\
\text { achievement level } \\
\text { the learners bef } \\
\text { involving in } \\
\text { learning processes. }\end{array}$ & $\begin{array}{l}\text { E-LEARNING } \\
\text { Application }\end{array}$ & $\begin{array}{l}\text { Tuesday, } \\
\text { March } 2020\end{array}$ \\
\hline Post-tes & $\begin{array}{l}\text { The same achievem } \\
\text { test to measure } \\
\text { achievement level } \\
\text { the e-learners at } \\
\text { learning with } \\
\text { implemented e-learn } \\
\text { system. }\end{array}$ & $\begin{array}{l}\text { E-LEARNING } \\
\text { Application }\end{array}$ & $\begin{array}{l}\text { Mon, } 13 \text { Ap } \\
2020\end{array}$ \\
\hline $\begin{array}{l}\text { Focus } \\
\text { Groups }\end{array}$ & $\begin{array}{l}\text { to get the grou } \\
\text { opinions regarding th } \\
\text { experiences with the } \\
\text { learning system }\end{array}$ & $\begin{array}{l}\text { Inside the buildings } \\
\text { the Faculty of Spec } \\
\text { Education/ } \\
\text { University } \\
\text { (Educational } \\
\text { Technology Dep.) }\end{array}$ & $\begin{array}{l}\text { Mon, } 6 \text { Al } \\
\text { 2020\& } \\
\text { Wednesday, } \\
\text { April } 2020\end{array}$ \\
\hline Intervie & $\begin{array}{l}\text { to collect rich det } \\
\text { about the efficacy of } \\
\text { Implemented } \\
\text { LEARNING }\end{array}$ & $\begin{array}{l}\text { Inside the buildings } \\
\text { the Faculty of Spec } \\
\text { Education/ } \\
\text { University } \\
\text { (Educational } \\
\text { Technology Dep.) }\end{array}$ & $\begin{array}{l}\text { From } 12 \text { to } \\
\text { April } 2020\end{array}$ \\
\hline
\end{tabular}

\section{Sampling}

The research sample are the learners who participated in the "printing \& binding" course in which e-learning is used as a tool to deliver the curriculum.

The Faculty of Specific Education was established in 1988. The Faculty follows Tanta University and has a department named "Instructional Technology" established to educate special kinds of 
future teachers with the ability to cope with modern technology and use it to enhance the Egyptian educational system.

This department is divided into two divisions: "computerteacher" division that is responsible for graduating computer teachers. The learners taught a lot of computer science curriculum, and the other division the "General Division" is responsible for graduating technical specialists for the educational aids used in the Egyptian schools.

As a result of the large number of learners (approximately 100 per year) in the same grade; both learners and tutors face difficulties such as: there is no specific or precise definition for the curriculum taught; and there is a tendency to concentrate on the theoretical side of the curriculum. This research is an attempt to search for the most appropriate method of delivery for the Egyptian higher education curriculum.

Many researchers have suggested that e-learning has proved its efficacy in improving the learning outcomes in diverse criteria (Bouhnik, 2006; Liaw, 2007; Raab, Ellis, and Abdon, 2002). This research will be conduct investigating the abilities of this method of delivery: "e-learning" to improve the learning and teaching of printing \& binding curriculum and thereby prove its efficacy for applying in the context of Egyptian higher education.

There were over (165 enrolled) in the E-LEARNING over the semester, with (65 participants) completing the units of the printing $\&$ binding course including (eleven groups) of learners. Each group contained from three to six learners. All the groups studied online units. (only 34 participants took the achievement test)

Indispensable success features for e-learning

E-learning systems' adoption is a complicated process as it comprises establishing, implementing, and developing a wide range of features to guarantee the successful integration of modern technology into the educational systems. The analyses of the data collected in this study identified numbers of e-learning Indispensable Success Features (ISF) based on stakeholders' perceptions and experiences. According to Papp (2000), and Selim (2007). 
Khan (2001) states that e-learning has been synonymously used with: web-based learning (WBL), Internet-based training (IBT), advanced distributed learning (ADL), web-based instruction (WBI), online learning (OL) and open/flexible learning (OFL). Moreover, using the Internet in distance learning looks synonymous to e-learning. This synonymy is reflected in the indispensable success features for distance learning and e-learning. Papp (2000), for instance, investigated distance learning and identified some indispensable success features (ISFs) that can assist in developing e-learning systems in educational institutions. These features included: e-learning platform, building the e-learning course, elearning course content, suitability of the course for e-learning environment, e-learning course maintenance, measuring the success of an e-learning course, and intellectual property. Similarly, Benigno and Trentin (2000) identified features such as student characteristics, learning materials, learning environment, studentstudent interaction, effective support, and information technology as a framework for evaluating e-leaning courses focusing on evaluating the learning, and students' performance.

The results

As mentioned previously, this research belongs to case study methodology where The researcher can use a whole spectrum of data collection tools underneath the case study umbrella. Thus, the research used an achievement test to get an insight regarding the level of knowledge development among the participants. The achievement test was established and verified for its validity and reliability. Therefore, it is used as a parametric tool after transforming it into an electronic format. "Parametric tests are more powerful than nonparametric tests because they not only derive from standardised scores but enable the researcher to compare subpopulations with a whole population." Cohen et al (2000: p. 318). The learners took this exam twice (pre-post): firstly, before they learn with e-learning; secondly, after they have learned using the suggested e-learning system. (See appendix 3)

Achievement Level

"The amount of information which I gained in e-learning is more than what I could have gained in Face to Face learning." 
This was the participant FG1-1 view regarding her gains and benefits from using e-learning system. Furthermore, the participant I1 explained her gains from e-learning in:

"I have gained a lot; there are information that I didn't know and there are more explanations by photos in addition, there is information about the sessions we are going to undertake."

Moreover, the participant FG4-3 stressed the capabilities of elearning to afford things which are difficult to afford in the FTF learning. As she puts it:

"There are things we cannot see practically in the faculty. Thus e-learning could afford them to us in a video which enable us to see them and to know their contents."

The questionnaire analysis shows learners' acknowledgement of the capabilities of e-learning to help them in their study. As it could be seen from table (2) that more than $90 \%$ of the participated learners have agreed (agreement includes strongly agree + agree) that e-learning can assist improving their knowledge in the curricula they have learned, while, only $3.7 \%$ of the learners disagreed. (See table "2")

\section{Table 2 The percentage distribution for The Learning Outcomes Items}

\begin{tabular}{l|l|l|l|l|l|l}
\hline Learning Outcomes & $\begin{array}{l}\text { Comparin } \\
\text { criteria }\end{array}$ & $\begin{array}{l}\text { Strong } \\
\text { Agree }\end{array}$ & Ag & $\begin{array}{l}\text { Do } \\
\text { Kno }\end{array}$ & Disag & $\begin{array}{l}\text { Strongl } \\
\text { Disagre }\end{array}$ \\
\hline $\begin{array}{l}\text { I believe e-learning } \\
\text { support improving } \\
\text { learner's knowledge }\end{array}$ & Count & 9 & 16 & 1 & 1 & - \\
\cline { 2 - 7 } & Percentage & 33.3 & 59.3 .7 & 3.7 & - \\
\hline $\begin{array}{l}\text { I believe e-learning } \\
\text { support improving learn } \\
\text { skills (performance) }\end{array}$ & Count & 5 & 16 & 4 & 2 & - \\
\cline { 2 - 7 } & Percentage & 18.5 & 59.14 .8 & 7.4 & - \\
\hline $\begin{array}{l}\text { I believe e-learning } \\
\text { develop } \\
\text { motivations }\end{array}$ & Count & 5 & 15 & 5 & 2 & - \\
\hline $\begin{array}{l}\text { I believe e-learning } \\
\text { assist improving }\end{array}$ & Count & 7 & 12 & 4 & 3 & 1 \\
\hline
\end{tabular}




\begin{tabular}{|c|c|c|c|c|c|c|}
\hline learner's understanding & Percentage & 25.9 & 44. & 14.8 & 11.1 & 3.7 \\
\hline \multirow{2}{*}{$\begin{array}{l}\text { I intend to use e-lear } \\
\text { to assist my learning in } \\
\text { future }\end{array}$} & Count & 5 & 9 & 10 & 3 & - \\
\hline & Percentage & 18.5 & 33. & 37 & 11.1 & - \\
\hline \multirow{2}{*}{$\begin{array}{l}\text { I intend to use e-learn } \\
\text { content to assist } \\
\text { learning in the future }\end{array}$} & Count & 6 & 12 & 9 & - & - \\
\hline & Percentage & 22.2 & 44. & .33 .3 & - & - \\
\hline \multirow{2}{*}{$\begin{array}{l}\text { I intend to use e-learn } \\
\text { activities to support } \\
\text { learning in the future }\end{array}$} & Count & 7 & 13 & 6 & 1 & - \\
\hline & Percentage & 25.9 & 48 & 22.2 & 3.7 & - \\
\hline \multirow{2}{*}{$\begin{array}{l}\text { I believe e-learning con } \\
\text { is informative }\end{array}$} & Count & 9 & 16 & - & 1 & 1 \\
\hline & Percentage & 33.3 & 59. & - & 3.7 & 3.7 \\
\hline \multirow{2}{*}{$\begin{array}{l}\text { I believe e-learning con } \\
\text { is useful }\end{array}$} & Count & 8 & 17 & 1 & 1 & - \\
\hline & Percentage & 29.6 & 63 & 3.7 & 3.7 & - \\
\hline \multirow{2}{*}{$\begin{array}{l}\text { I believe e-learning } \\
\text { useful method } \\
\text { curriculum delivery }\end{array}$} & Count & 2 & 14 & 5 & 5 & 1 \\
\hline & Percentage & 7.4 & 51. & 18.5 & 18.5 & 3.7 \\
\hline \multirow{2}{*}{$\begin{array}{l}\text { I believe I can use } \\
\text { knowledge I } \text { gai } \\
\text { effectively in my work }\end{array}$} & Count & 10 & 10 & 5 & 2 & - \\
\hline & Percentage & 37 & 37 & 18.5 & 7.4 & - \\
\hline
\end{tabular}

Learners' satisfaction toward the usefulness of e-learning in enhancing their knowledge represents an indication that e-learning retain such efficacy. Nevertheless, it could be supported by the (achievement test) results, which could confirm or reject the learners' point of view.

In order to make sure that there are significant differences in the achievement levels between the research group before and after learning with the e-learning system. An achievement test has been taken by the participated learners twice (before and after learning with e-learning). The significance of differences is calculated using "t-Test", which lead to the result shown in table (3). 
Table 3 the significant of ( $t$ ) to the differences between the learners group in the achievement test in both pre-test and post-test.

\begin{tabular}{l|l|l|l|l|l|l}
\hline Measure & Group & Number & Mean & $\begin{array}{l}\text { Std. } \\
\text { Deviation }\end{array}$ & t & Sig. \\
\hline Pre-test & Group 1 & 34 & 4.09 & 2.021 & 11.007 & 0.001 \\
\hline Post-test & Group 1 & 34 & 7.49 & 1.626 & & \\
\hline
\end{tabular}

As a result of comparing the means of the participants' two attempts to solve the achievement test (pre and post-test) there is a significant difference between the two measures at the level of lower than 0.0001 in favour of the post-test. This could indicate that learners' knowledge achievement have increased, which could be a direct result of the use of the implemented e-learning, because learners didn't learn anything about the taught curriculum but from the implemented e-learning.

Additionally, to identify the amount of influence $\eta 2=\mathrm{t} 2 /(\mathrm{t} 2+$ df) is calculated, which results as: $\eta 2=0.786$. From this, it appears that $\eta 2>(0.15)$, which shows that the implemented E-LEARNING is effective in enhancing the learners' achievement level in printing $\&$ binding curricula. Thus, the research anticipates that the developments in the learners' achievement levels could be due to their learning using e-learning. This anticipation reinforces the learners' views that e-learning have a positive effectiveness on enhancing their knowledge.

regarding the efficacy of e-learning on the motivation to learn, almost $74 \%$ of the learners saw that e-learning can improve their learning motivations, while $7.4 \%$ of the learners did not agree on that. Simultaneously, more than $70 \%$ of the participated learners believe that e-learning can assist improving their understanding. On the contrary, almost $15 \%$ of the learners didn't approve that elearning can assist them to improve their understanding.

After applying the achievement test (pre-post), learners are predicted to be fully aware of the potentials that e-learning provide learners with. Hence, they can give a reliable recommendations and features that should be available in successful e-learning implementation into Egyptian higher education sector. 
As is shown in (Figure 1), the data analysis, in the present study, identified a number of emerging themes i.e., (indispensable success features) for implementing e-learning.

Discussion of the results:

The purpose of this research is to: examine the effectiveness of e-learning; and present Indispensable Features to Successful Implementation for E-Learning in the Egyptian Higher Education. Therefore, this research gains its importance from:

1. The unique structure to examine the effectiveness of e-learning for the Egyptian higher education;

2. Establishing a group of Indispensable Successful Implementation Features for E-Learning in the Egyptian Higher Education.

The research questions were:

1. What are the Indispensable Successful Implementation Features for E-Learning in the Egyptian Higher Education?

2. What is the effectiveness of using e-learning on learners' achievement level in the "printing \& binding" course?

The answer of Research Question 1

The answer to the first research questions - What are the Indispensable Successful Implementation Features for E-Learning in the Egyptian Higher Education? incorporates the sub-questions:

1. What is meant by Indispensable Successful Implementation Features?

2. What are the participants' recommendations that drawn the Indispensable Successful Implementation Features for E-Learning in the Egyptian Higher Education?

3. What are the Indispensable Successful Implementation Features?

The question - What is Indispensable Successful 
Implementation Features? The research clarified that indispensable success features are based around the quadrant of curriculum, tutors, learners and technology. It is the term used by many researchers to define the elements that would assist higher education institutions in efficient and effective e-learning adoption.

The specified success features, based on stakeholders' perceptions and expertise, include: The specifications of the course content; Tutors' features (attitudes towards e-learning, technological proficiency, and support); Learners' features (computer competency, English language proficiency, and learning styles); and technology (usability, finances, and infrastructure).

The question What are the participants' recommendations that drawn the Indispensable Successful Implementation Features for ELearning in the Egyptian Higher Education? Could be answered by exploring the participants' views and opinions regarding their experience in learning with e-learning as they stated it in the next discussion.

The specifications of the course

Data analysis indicated that participants strongly viewed The specifications of the course as one of the main features to initiate a successful e-learning system.

"At the beginning, there has to be an adaptation for curriculum to fit with e-learning; not all curriculums are suitable for teaching with e-learning."

This was participant FG4-1 statement when she answered the question concerning the features that guarantee successful elearning systems. She uncovered her views regarding the necessity of making an adaptation processes for any curriculum that needed to be taught with e-learning. She believed that "e-learning is not a suitable suit for everybody" and e-learning cannot adopt any curriculum without developing and deploying in a way that fits with the e-learning suit.

By "The specifications of the course", the participants meant to focus on the curriculum content - whether to be theoretical or practical. 
In addition, the participants' views regarding the best curriculum nature to fit the e-learning systems were contradictory; many of them saw that e-learning, in their opinion, fits more with the practical curriculum contents. On the other hand, others intensified their belief that e-learning courses fit easily with the theoretical curriculum contents.

Moreover, participant FG4-2 thought that a theoretical curriculum is more likely to be hosted by e-learning systems. As she puts it:

"On the contrary, theoretical will be easier, there will be no need for a lot of explanations and it will be easier to read and learn."

Above all, participant FG7-4 stated that a theoretical curriculum would be much better in learning or as she stated:

"A Theoretical curriculum will be much, much, much more convenient in e-learning systems."

On the contrary, many participants indicated that the practical curriculum will be easier to implement in e-learning systems. According to participant FG4-3 puts it:

"Indeed, the theoretical curriculum cannot be implemented in e-learning systems; It does not have but one way to be understood and that is the book way. Thus, I cannot understand it unless I listen to the tutor's explanation face-to-face because I will need to ask him/her a question every five minutes. On the contrary, in a practical curriculum I can learn with many different methods and tools."

Added to that, participant FG4-3 refers the preference of learning practical curriculum through e-learning to the lack of affordances inside the educational institutions, which makes her prefer e-learning systems to overcome the insufficient materials challenge. As she states:

"E-learning enables us to see some elements that we cannot afford to see with our own eyes in the faculty. Thus, it will be available in the e-learning resources as video, which enable us to see and know about them." 
to conclude, as is shown, the participants' point of view asserts that The specifications of the course content is a basic factor for elearning successful implementation. The specifications of the course content, side by side with the adaptation process which is essential to convert any curriculum into an electronic format are indispensable success features for implementing e-learning inside higher education.

\section{Tutors' features}

The participants emphasised the tutor's role and expertise in elearning courses successful implementation. Compared to the traditional classroom instruction, e-learning tutors are faced with additional tasks such as: developing coherent well-structured resources that are also technically well-designed (in case they design the system as well as the content); and providing challenging opportunities for e-learning activities whether individual or collaborative ones.

Participant FG3-2 stated the Tutors' features saying:

"The tutor who designed an e-learning course must be skilful, profoundly understands the learners' nature, and considers the learners' circumstances."

Meanwhile, participant FG3-4 added another characteristic of successful e-learning tutor - "loves the curriculum s/he teaches". As she puts it:

"One of the boundaries of a successful tutor is the possibility that a tutor could teach a curriculum that s/he does not like because s/he is forced by the regulation in the educational institution."

Along the same vein, participant I3 added another important successful tutor characteristic:

"Unfortunately, communication in e-learning is far more difficult than in the FTF learning. Thus, if the tutor is a failure communicator in FTF learning I suspect s/he will be more successful in e-learning. This is from experience with both methods of delivery."

Similarly, participant I5 provided a specific description of the successful e-learning tutor in: 
"The successful e-learning tutors have to believe in e-learning as a delivery method and s/he has to obtain certain characteristics such as: understanding; realising his/her part in the learning process using e-learning systems; and fully aware of the cons and pros of elearning systems."

These points highlight some of the main characteristics of the successful e-learning tutors, which emerged from the participants' views and opinions.

\section{Learners' features}

Higher education students in Egypt have their own traits, which, unfortunately, represent a serious threat to successful elearning implementation. The first Learners' features was their low English language level. This could be identified in participant's FG4-3 complaints about the video files which were in English:

"The English video was difficult to understand; they were talking with very difficult accent to understand."

Similarly, participant FG4-1 stated:

"The English explanations need someone experienced in English; it is not just someone who knows a little bit of English could understand them. It needs someone whose native tongue is English."

This shows that some of the participants in Egyptian higher education students are facing challenge with their English language level, which needs attention for successful e-learning implementation in Egyptian higher education.

Participant FG7-2 uncovered another indispensable success factor - in the Learners' features - for e-learning implementation in higher education. In her exact words:

"I have been studying with FTF for 12 years now, and all of sudden I found a tutor telling me that I am going to learn by elearning. I cannot learn like this."

In the last statement, the participant has identified an indispensable factor, namely, the familiarity with a certain delivery method that was generated because using such method for a long time without giving learners any chance to experience other 
delivery methods.

Thus, it is a good advice to address this factor before involving in e-learning implementation in Egyptian higher education. This would be achievable by training learners on e-learning courses starting as early as (primary schools) trying to eliminate learners' unfamiliarity factor from e-learning and to get them accustomed to the new e-learning delivery method.

Another dimension added to the Learners' features indispensable success factor is learners' computer and internet competency. It is clear that Egyptian learners suffer from insufficient computer skills and disconnection from the internet revolutionary usage in learning (maybe they have great skills in the usage of social networking, but then again not having the same talent in exploiting the possibilities of the web to learn). According to participant I5:

"E-learning needs time and effort to teach the learners the required skills to succeed in using it in what is called "pre-required skills" because, basically, Egyptian learners do not know the required skills to operate computers. Thus, they need a training course to give them the required skills to interact with computers and e-learning environments."

The last statement of the participant I5 clearly shows that in order for e-learning to be successfully implemented in Egyptian higher education sector, the problem of learners' incompetency in computer and surfing Internet for particular exploration needs to be taken care of.

The last dimension in the Learners' features success factor is the learners' learning style or their learning preferences. Whether is dependent or independent the learner could make a difference in making an e-learning system successful or not. As participant FG72 explained her preferences to learn depending on her tutor saying:

"I used to learn through the internet just when I am forced to. For instance, when our tutor asks us to do a search on the internet; in such cases, I am forced to use the internet to do it but not to learn by myself."

In addition, in her words, participant FG1-2 supported the 
effect of learning style saying:

"Nevertheless, there are certain topics I could not understand on my own; someone has to explain them for me because I will not understand everything alone."

The last quote clearly shows that learners have variety of learning styles including dependent learning style (where learners only learn the whole information spectrum with the support of others such as tutor). This is not a lack of learning competence (learning to learn) because predispositions towards learning in a certain way or settings are included in the next learning styles definition.

As stated by CIPD (2008), a "learning style" includes three main parts, identified as:

Information processing - habitual modes of perceiving, storing and organising information (for example, pictorially or verbally).

Instructional preferences - predispositions towards learning in a certain way (for example, collaboratively or independently) or in a certain setting (for example, time of day, environment)

Learning strategies - adaptive responses to learn specific subject matter in a particular context.

The last statement shows that learner's learning style has interfered with her ability to fully learn using e-learning system. Yet, some of the participants have attributed the problem to the unfamiliarity with e-learning as a new delivery method.

Participant FG1-2 suggested a solution for the e-learning systems unfamiliarity problem: it:

"There should be educational courses to learners to get them to know how to learn with e-learning and how to interact with the computer alone without anyone beside him to help."

Thus, through the participants' responses, it becomes clear that the learners learning style could be an important element to push the learner either to use the e-learning system or to disregard it. Regarding the familiarity with the e-learning systems, it is quite simple to overcome this problem; either by giving the learners preparatory courses as was suggested by participant FG1 -2 or by 
other possible means.

Technological feature

"The only barrier for successful e-learning is that there are no finances for it in the first place. The problem is not related to whether we want to use it in learning or not. It is all about affordances."

These were the words of participant FG7-4 in response to a question on what represented a barrier against her learning with elearning.

In addition, participant FG7-1 defined some elements to be addressed if a successful e-learning system is to be implemented:

"Finances, we are short in finances, the fresher to study Internet \& the principals of e-learning, and of course the computers; you can see only two or three devices are working. Or should we bring our own devices!"

This simply shows that financial and technical issues from the participants' views represent an indispensable success factor for elearning implementation in Egyptian higher education. In fact, this might be the case in many countries' higher education sectors not just the Egyptian ones. All over the world, many countries suffer from the lack of financial and technical affordances, that affects the learners' abilities of efficiently interact with e-learning systems.

The question "What are the Indispensable Successful Implementation Features?" could be answered in the next Figure: 


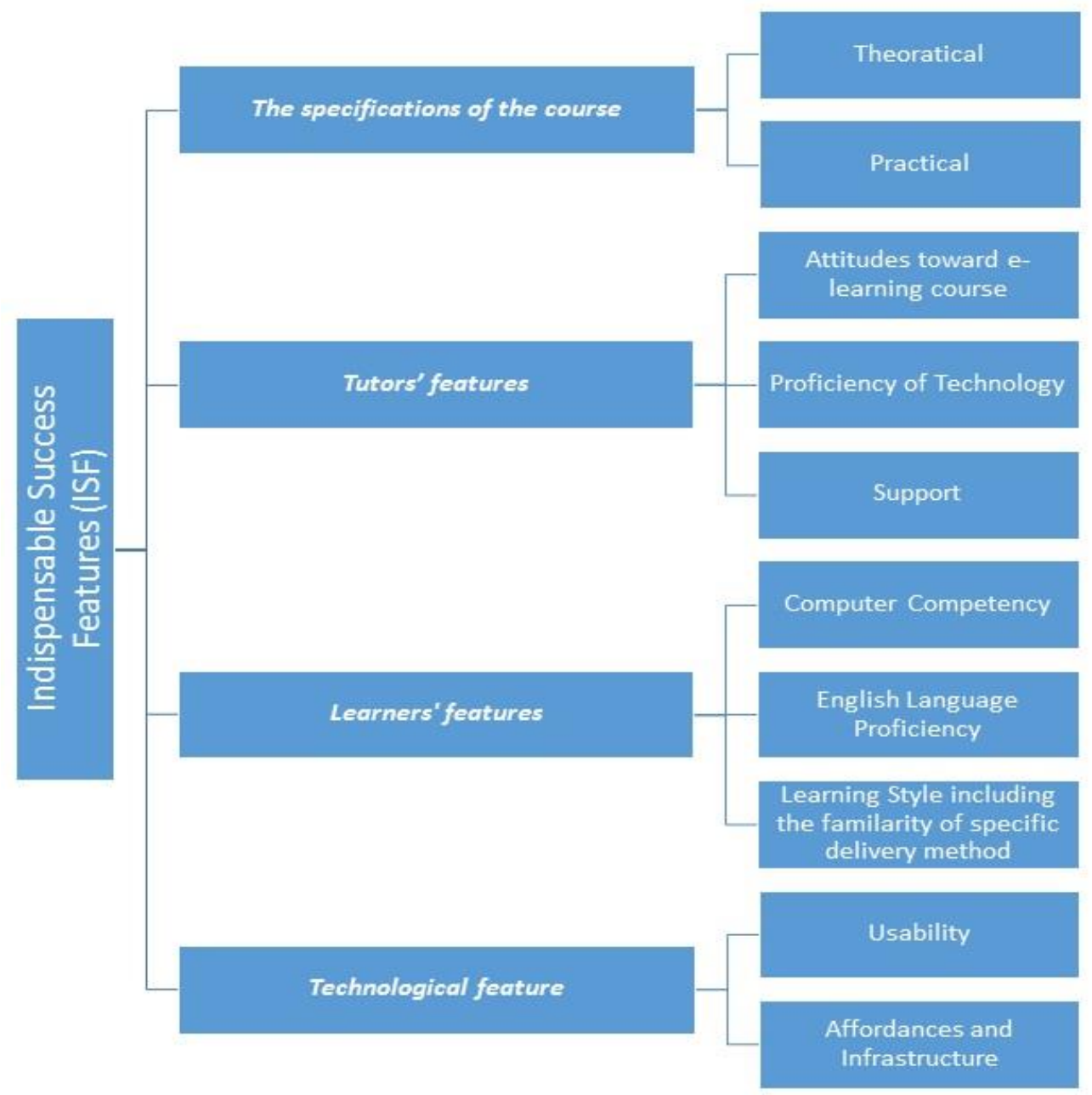

Figure 2: Indispensable Success Features (ISF)

The answer of Research Question 2

The answer of the second research question: - What is the effectiveness of using e-learning on learners' achievement level in the "printing \& binding" course? demands the assessment of elearners' achievement levels on the taught units in the "printing \& binding" course using (pre-post achievement test). And then use t-test to measure the means of the research sample different (significant). The results of using t-test is demonstrated in table (3)

From the results in table (3) it is obvious that the value of (t) is significant on a significant level (0.001), which indicate that there is 
a significant difference between the means of the research group's degrees on pre and post-test for the sack of the post-test, which indicates that there is an improvement happened in the learners' achievement levels on the achievement test after learning with the implemented e-learning system. This is supported by many research in the literature (Health Libraries Group, 2005; D. H. Lim, Morris, M. L., \& Kupritz, V. W., 2006; New Zealand Council for Educational Research, 2004 ‘Niehues-Jeuffroy, H., \& Rusnak, O., 2020).

Thus, the research anticipates that the developments in the learners' achievement levels could be due to the next reasons:

4. Using the e-learning as a solely learning delivery method for their curricula, which reinforces the learners' views that e-learning have a positive effectiveness on enhancing their knowledge.

5. The usage of both personalised and collaborative activities inside the e-learning have increased learners' motivations to learn.

6. The availability of various resources enabled learners to reinforce their learning.

7. The novelty of the idea of using e-learning to the Egyptian higher education learners helped them to incorporate e-learning as a delivery method although they confronted with many challenging barriers.

8. The fast feedback given to learners over e-learning represented reinforcement for the learners.

Summary and conclusions

This study addresses the challenge currently facing higher education in Egypt. Although the study focuses on just one of the governmental universities, the results can be generalised (Cohen et al., 2007) to similar provisions and the reflection on the model of indispensable success features has implications for e-learning development in more advanced countries.

Although the TEARS model (Leggett \& Persichitte, 1998) identifies areas of concern, yet the themes arising from the 
grounded analysis of qualitative data suggests the conceptual quadrant of curriculum, tutors, learners and Technological feature and lead the discussion of "the e-Learning".

The participants of the study identified important features that they saw as crucial to the successful implementation of e-learning (See figure 1). Through analysis of participants' responses, the study identified a number of e-learning indispensable success features (ISF). This is the term used by many researchers to define the elements that would assist higher education institutions in efficient and effective e-learning adoption and guarantee e-learning systems quality implementation (Papp, 2000; Selim, 2007).

The specified success features, based on stakeholders' perceptions and expertise, include: The specifications of the course content; Tutors' features (attitudes towards e-learning, technological proficiency, and support); Learners' features (computer competency, English language proficiency, and learning styles); and Technological feature (usability, finances, and infrastructure).

The result of the present study and the identified features are consistent with the literature. For example, Papp (2000) investigated distant learning and suggested some indispensable success features (ISFs) that can assist Educational institutions in e-learning systems development. They included intellectual property, suitability of the course for e-learning environment, building the e-learning course, elearning course content, e-learning course maintenance, e-learning platform, and measuring the success of an e-learning course. similarly, Yaghoubi et al. (2008: p. 90) defined many critical problems, which face The transaction process from traditional education into a modern one including defective implementation of computer hardware and software, weak IT infrastructure, the absence of the realistic point of view or strategic programme for higher education. In addition, Benigno and Trentin (2000) considered features such as student characteristics, student-student interaction, effective support, learning materials, learning environment and information technology. Moreover, Selim (2010: p. 338) stated that "the instructor's attitude toward e-learning, learners, and his/her mastery of the technology is motivating the 
learners to accept e-learning. Furthermore, Nesterchuk, Grishin, and Chepurnaya (2020) defined elements that are crucial to be approached in higher education digitalization after the COVID19 pandemic in: the promising auxiliary tools that can be used in the field of organizing digital education to improve the distance work: Google forms, OnlineTestPad and other platforms ؛weak motivation and the lack of the ability to organize effective control of students' knowledge !In conditions of distance work, students are often distracted, unable to concentrate.

Above all, the additional features the participants identified in the study are also consistent with the literature that suggested other features and explained their importance for the successful e-learning systems implementation (Ali, 2008; Coman, 2002; Jara, 2009; McPherson, 2008; New Zealand Council for Educational Research, 2004).

In this research the participants have experienced the whole spectrum of e-learning from learning till evaluation, and through the research tools (questionnaire, interview and focus group). The participants, have identified, discussed, and explained a number of important features that need to be addressed for successful elearning implementation: The specifications of the course content (theoretical, practical); tutor characteristics (attitude towards elearning, proficiency of the technology, and support); Learners' features (computer competency, English language proficiency, and learning style); and Technological feature (usability, finances, and infrastructure).

In conclusion, the researcher believes that systematic consideration of the features identified in the presents study elearning and blended learning implementation would be more effective and efficient. 


\section{References}

Abdel-Wahab, A. G. 2008. 'Modeling Students' Intention to Adopt E-learning: A Case from Egypt'. Turkish Online Journal of Distance Education, 9/1.

Abercrombie, N., Hill, S., \& Turner, B. S. (Ed.) (1984). UK: Penguin.

Al-araibi, A. A., bin Mahrin, M. N., Yusoff, R. C., \& Chuprat, S. B. (2019). A model for technological aspect of e-learning readiness in higher education. Education and Information Technologies, 24, 1395-1431. doi:10.1007/s10639-018-98379

Ali, G. E., \& Magalhaes, R. 2008. 'Barriers to implementing elearning: a Kuwaiti case study'. International Journal of Training and Development, 12/1.

Ali, L. (2018). The Design of Curriculum, Assessment and Evaluation in Higher Education with Constructive Alignment. Journal of Education and e-Learning Research, 5(1), 72-78. doi:10.20448/journal.509.2018.51.72.78

Antonacci, M. D. 2002. Integrating Technology into Instruction in Higher Education. Accesses 30 March 2010, Available at http://74.125.155.132/scholar?q=cache:kJk7cIbTw $\mathrm{kJ}$ :scholar.google.com/+Integrating+Technolo gy+into+Instruction+in+Higher+Education\&hl=en\&as $\mathrm{sdt}=2000 \&$ as vis $=1$

Beckstrom, M., Croasdale, H., Riad, S. M., \& Kamel, M. 2004. Assessment of Egypt's Learning Readiness. Accessed 1 December, 2008, Available at http://www.ltss.bris.ac.uk/events/egypt/ellen/readiness.doc

Benigno, V., and Trentin, G. 2000. 'The evaluation of online courses'. Journal of Computer Assisted Learning, 16: 259270.

Bloor, M., Frankland, J., Thomas, M., \& Robson, K. 2001. Focus Groups in Social Research. London: SAGE Publications Ltd. Bouhnik, D., \& Marcus, T. (2006). Interaction in Distance-Learning Courses. Journal of the American Society Information Science and Technology, 57(3), 299-305.

CIPD. 2008. Learning styles. Accessed 9 February, 2011, Available at 
http://www.cipd.co.uk/subiects/lrnanddev/general/lrngstyls.h tm

Cohen, L., Manion, L., \& Morrison, K. (2000). Research Methods in Education (5th ed.). NewYork Routledge Group.

Cohen, L., Manion, L., \& Morrison, K. 2007. Research Methods in Education. (Sixth Edition ed.). NewYork, US: Routledge Group.

Coman, P. G. (2002). 'Critical Success Features for eLearning Delivery'. Paper presented at the International Conference on Computers in Education (ICCE'02).

Corbin, J. M., \& Strauss, A. . (1998). Basics of Qualitative Research: Techniques and Procedures for Developing Grounded Theory. New York: Sage.

Creswell, J. W. (2007). Qualitative Inquiry and Research Design: Choosing among Five Traditions. London: SAGE Publications.

Davis, F. D. (1989). 'Perceived usefulness, perceived ease of use, and user acceptance of information technology'. MIS Quatterly, September: 319-340.

Glaser, B. G., \& Strauss, L. (1967). The Discovery of Grounded Theory: Strategies for Qualitative Research. Chicago: Aldine.

Gillham, B. (2004). Case Study Research Methods. London: Continuum.

Jaques, D. (1994). Learning in Groups. Retrieved 9 june, 2008, from <http://www.studygs.net/casestudy.htm>

Jara, M., \& Meller, H. 2009. 'Features affecting quality enhancement procedures for e-learning courses'. Quality Assurance in Education, 17/3: 220-232.

Khan, B. H. 2001. 'A framework for Web-based learning' In Khan, B. H. (ed.) Web-based Training. Educational Technology Publications: pp. 75-98.

Lee, M.-C. 2010. 'Explaining and predicting users continuance intention toward e-learning: An extension of the expectationconfirmation model'. Computers \& Education, 54/2010: 506516.

Leggett, P. W., and Persichitte, A. K. (1998). 'Blood, Sweat, and TEARS: 50 Years of Technology Implementation Obstacles'. TechTrends, 43/3: 33-36. 
Liaw, S. S., Huang, H. M., \& Chen, G. D. (2007). An ActivityTheoretical Approach to Investigate Learners' Factors Toward E-Learning Systems. Computers in Human Behavior, 23, 1906-1920.

McPherson, M. A., \& Nunes, J. M. 2008. 'Critical issues for elearning delivery: what may seem obvious is not always put into practice'. Journal of Computer Assisted Learning, 24/5.

Ministry of Communications and Information Technology. (2010).

Egyptian Education Initiative. accessed 2 June 2010, Available at

http://www.eei.gov.eg/pages/01\%20About\%20EEI/Objective s.aspx

Ministry, C. I. T. (2020). 'Information and Communications Technology Indicators Bulletin'. accessed 24 Aug. 21, Available

https://mcit.gov.eg/Upcont/Documents/Publications_161120

20000_ICT_Indicators_Quarterly_Bulletin_Q2_2020.pdf

NCERD. (2001). 'Education Development'. Cairo, Egypt: National

Center for Educational Research and Development

Nesterchuk, O. A., Grishin1, O. E., and Chepurnaya, A. M. (2020).

Journal of Physics: Conference Series. 1691012068

New Zealand Council for Educational Research. 2004. 'Critical Success Features and Effective Pedagogy for e-learning in Tertiary Education'. Background paper for ITP New Zealand, WELLINGTON.

Niehues-Jeuffroy, H., \& Rusnak, O. (2020). CAN E-LEARNING BE A SOLUTION FOR EGYPTIAN HIGHER EDUCATION IN THE TIMES OF COVID-19? A LOOK AT TECHNOLOGICAL CAPACITIES AND DIGITAL SKILLS. European Distance and E-Learning Network (EDEN) Proceedings 2020 Annual Conference | Timisoara, 22-24 June, $2020 . \quad$ Available at: file:///C:/Users/tamer/Downloads/1059-932-1-PB.pdf

Papp, R. 2000. 'Critical success features for distance learning'. Paper presented at the Americas Conference on Information Systems (AMCIS).

Raab, R. T., Ellis, W. W., \& Abdon, B. R. (2002). Multisectoral Partnerships in E-Learning A Potential Force for Improve 
Human Capital Development in the Asia Pacific. Internet and Higher Education, 4, 217-229.

Selim, H. M. 2007. 'Critical success features for e-learning acceptance: Confirmatory factor models'. Computers \& Education, 49: 396-413.

Selim, H. M. 2010. 'Hybrid E-Learning Acceptance Model: Learner Perceptions'. Decision Sciences Journal of Innovative Education, 8/2.

Simons, H. (2009). Case Study Research in Practice London: SAGE.

Stake, R. E. (1995). The Art of Case Study Research. London: SAGE Publications.

UNESCO. 2003. 'Higher education in the Arab Region 1998-2003'. Paris: Document prepared by UNESCO Regional Bureau for Education in the Arab States.

UNESCO. 2021. "The 2023 GEM Report on Technology and Education Overview." Paris: An overview prepared by UNESCO Global Education Monitoring Report. accessed 21 Sep. 2021, Available at: https://2023gemreportconsultation.wordpress.com/

UNESCO, UNICEF, the World Bank and OECD (2021). What's Next? Lessons on Education Recovery: Findings from a Survey of Ministries of Education amid the COVID-19 Pandemic. Paris, New York, Washington D.C.: UNESCO, UNICEF, World Bank.

Warschauer, M. 2003. 'Dissecting the "Digital Divide": A Case Study in Egypt'. The Information Society, 19/4: 297-304.

Wu, J.-H., Tennyson, R. D., \&Hsia, T.-L. 2010. 'A study of student satisfaction in a blended e-learning system environment'. Computers \& Education 55/2010: 155-164.

Yaghoubi, J., Mohammadi, I. M., Iravani, H., Attaran, M. and Gheidi, A. 2008. 'virtual students' perceptions of e-learning in Iran.' The Turkish Online Journal of Educational Technology $7 / 3$.

Yin, R. 2003. 'Case Study Research: Design and Methods'. London: SAGE Publications. 


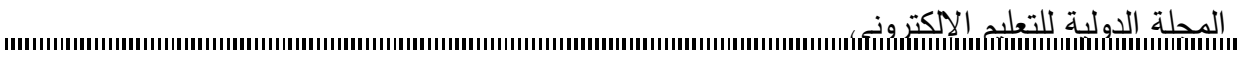

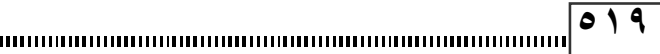

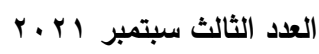

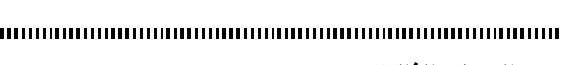
المجلد الثالث 